Peer-reviewed research

\title{
A Note on the Asian Market Volatility During the COVID-19 Pandemic
}

\author{
Susan Sunila Sharma ${ }^{1}$ \\ 1 Deakin University, Melbourne, Australia \\ Keywords: asian regional volatility, country-level, volatility, covid-19 \\ https://doi.org/10.46557/001c.17661
}

\section{Asian Economics Letters}

Vol. 1, Issue 2, 2020

\begin{abstract}
This paper provides a note on commonality in volatility for five developed Asian economies, namely Hong Kong, Japan, Russia, Singapore and South Korea. Additionally, we examine whether the COVID-19 pandemic changed the commonality in volatility within the Asian region. Overall, we find that commonality in volatility during the COVID-19 period is more prominent in the case of Singapore compared to other four economies.
\end{abstract}

\section{Introduction}

This note provides evidence on the role of COVID-19 in influencing commonality in volatility in five developed Asian economies, namely the special administrative region of the Peoples Republic of China, Hong Kong (HK), Japan, Russia, Singapore, and South Korea (S. Korea). In other words, we examine whether market volatility at the Asian regional level can explain stock market volatility at the country-level. Recent studies have shown that the COVID-19 pandemic has significantly affected global economies; see, for instance, Mishra et al. (2020), Salisu \& Akanni (2020), Chen et al. (2020), Wang et al. (2020), Yue et al. (2020), Yu et al. (2020), Xiong et al. (2020), Shen et al. (2020), Gu et al. (2020), Haroon \& Rizvi (2020), Iyke (2020), He et al. (2020), and Liu et al. (2020). According to Sha \& Sharma (2020) and Phan \& Narayan (2020), the COVID-19 pandemic represents the largest and most disturbing shock to the global economic system and it is therefore important to understand whether the country level volatility can be determined by the regional level stock market volatility.

Our hypothesis is motivated by evidence in the literature that aggregate stock market volatility explains sectoral level volatility (see Sharma et al., 2014). In other words, Sharma et al. (2014) hypothesize that volatility at an aggregate level can exert a "spillover effect" and/or a "contagion" effect at the disaggregate (firm) level. However, it has not been examined whether the volatility "spillover effect" and/or "contagion effect" exists during periods when stock markets are more vulnerable and volatile due to the obvious structural shifts, such as those observed as a result of the COVID-19 pandemic (see Devpura et al., 2019; and Zhang et al., 2020). Spillover is defined as a situation where a dominating market leads to a change in the less dominated market. An aggregate regional stock market, therefore, is a composite function of the number of stock markets in the region and, therefore, the country-level market and the aggregate regional market share some economic ties (see Sharma et al., 2014). Thus, volatility spillover occurs when volatility originates in the region and spills over to all the stock markets within that region. On the other hand, Forbes and Rigoben (2002, p. 2224) define contagion as "it is only contagion if cross-market movements increase significantly after the shock". In fact, a number of studies have argued that there is a significant increase in the degree of co-movement between stock returns in different countries following a shock (see for instance, Rigobon, 2003; Rodriguez, 2007).

Thus, our idea of examining commonality in volatility is important and also it is unique because we test whether commonality in volatility in the Asian stock markets observed during the pre-COVID-19 period remains also during the COVID-19 period. By doing so, our study contributes to two sets of literatures: (a) studies which examine the relationship between aggregate market volatility and firm level volatility; and (b) studies which examine the influence of COVID-19 on the stock market. First, we contribute by providing evidence that regardless of the volatility measure employed, the regional level market volatility has a statistically significant effect on country level volatility. Second, we contribute, by showing that the COVID-19 pandemic has a heterogenous effect on country level volatility. In the case of Singapore, for instance, we show that stock market volatility is strongly influenced by the aggregate Asian regional level market volatility during the COVID-19 pandemic period, whereas for the remaining four Asian economies, the overall effect is dependent on different proxies for volatility.

The balance of the paper is organised as follows. In the next section, we discuss data and provide a discussion on the empirical model. Section III discusses the main findings; and, in the final section, we provide some concluding remarks.

\section{Data and Methodology}

\section{A. Data}

In this section, we describe our dataset. In order to compute stock market volatility, we extract daily data on high price (HP), low price (LP), opening price (OP), and closing price (CP) of the Nikkei 225 stock index (Japan), the MOEX Russia index (Russia), the Heng Seng price index (HK), the Straits Times index (Singapore), and the Korea Se Composite price index (S. Korea). All price data are sourced from DataStream. 
Table 1: Data description and descriptive statistics

Panel A: Data description

\begin{tabular}{|c|c|c|c|c|c|c|c|c|c|}
\hline Variable & \multicolumn{9}{|c|}{ Description } \\
\hline$V_{1}$ & \multicolumn{9}{|c|}{ Parkinson (1980) approach: $V_{1}=0.361\left[\ln \left(\frac{\mathrm{HP}}{\mathrm{LP}}\right)\right]^{2}$} \\
\hline$V_{2}$ & \multicolumn{9}{|c|}{ German \& Klass (1980) approach: $V_{2}=0.5[\ln (H P)-\ln (L P)]^{2}-[2 \ln 2-1][\ln (C P)-\ln (C P)]^{2}$} \\
\hline$V_{3}$ & \multicolumn{9}{|c|}{ Rogers \& Satchell (1991) and Rogers et al. (1994) approach: $V_{3}=[\ln (H P)-\ln (O P)][\ln (H P)-\ln (C P)]+[\ln (L P)-\ln (O P)][\ln (L P)-\ln (C P)]$} \\
\hline$M V 1, M V 2$, and $M V 3$ & \multicolumn{9}{|c|}{ Aggregate five Asian stock market volatility which is measured as follows: $M V 1=\sum_{i=1}^{n} V_{1 i} ; M V 2=\sum_{i=1}^{n} V_{2 i}$; and $M V 3=\sum_{i=1}^{n} V_{3 i}$. Note $n=5$ which represents five Asian economies. } \\
\hline \multicolumn{10}{|c|}{ Panel B: Descriptive statistics } \\
\hline & Variable & Mean & Maximum & Minimum & Std. Dev. & Skewness & Prob of JB & Prob of ADF test & Sample size \\
\hline \multirow{3}{*}{$\mathrm{HK}$} & $V_{1}$ & 0.0001 & 0.0112 & 0.0000 & 0.0002 & 23.6262 & 0.0000 & 0.0000 & \multirow{3}{*}{ 01/03/2000 - 09/25/2020 (5410 obs.) } \\
\hline & $V_{2}$ & 0.0001 & 0.0104 & 0.0000 & 0.0002 & 23.4007 & 0.0000 & 0.0000 & \\
\hline & $v_{3}$ & 0.0001 & 0.0089 & 0.0000 & 0.0002 & 18.3253 & 0.0000 & 0.0000 & \\
\hline \multirow{3}{*}{ Japan } & $V_{1}$ & 0.0001 & 0.0068 & 0.0000 & 0.0002 & 12.6354 & 0.0000 & 0.0000 & \multirow{3}{*}{ 01/03/2000 - 09/25/2020 (5410 obs.) } \\
\hline & $V_{2}$ & 0.0001 & 0.0061 & -0.0004 & 0.0002 & 12.9398 & 0.0000 & 0.0000 & \\
\hline & $v_{3}$ & 0.0001 & 0.0092 & -0.0000 & 0.0002 & 16.4319 & 0.0000 & 0.0000 & \\
\hline \multirow{2}{*}{ Russia } & $V_{1}$ & 0.0003 & 0.0274 & 0.0000 & 0.0009 & 14.3004 & 0.0000 & 0.0000 & \multirow{2}{*}{ 01/08/2005 - 09/25/2020 (4623 obs.) } \\
\hline & $v_{3}$ & 0.0003 & 0.0205 & -0.0005 & 0.0008 & 11.3925 & 0.0000 & 0.0000 & \\
\hline \multirow{3}{*}{ Singapore } & $V_{1}$ & 0.0001 & 0.0055 & 0.0000 & 0.0002 & 13.7248 & 0.0000 & 0.0000 & \multirow{3}{*}{ 01/15/2008 - 09/25/2020 (3314 obs.) } \\
\hline & $v_{2}$ & 0.0001 & 0.0033 & -0.0012 & 0.0002 & 9.9344 & 0.0000 & 0.0000 & \\
\hline & $v_{3}$ & 0.0001 & 0.0030 & -0.0009 & 0.0002 & 8.9938 & 0.0000 & 0.0000 & \\
\hline \multirow{3}{*}{ S. Korea } & $V_{1}$ & 0.0001 & 0.0091 & 0.0000 & 0.0003 & 13.2155 & 0.0000 & 0.0000 & \multirow{3}{*}{ 01/03/2000 - 09/25/2020 (5410 obs.) } \\
\hline & $v_{2}$ & 0.0001 & 0.0102 & -0.0010 & 0.0003 & 14.6427 & 0.0000 & 0.0000 & \\
\hline & $V_{3}$ & 0.0001 & 0.0098 & -0.0022 & 0.0003 & 12.0419 & 0.0000 & 0.0000 & \\
\hline MV1 & & 0.0001 & 0.0064 & 0.0001 & 0.0002 & 14.7244 & 0.0000 & 0.0000 & \\
\hline$M V 2$ & & -0.0044 & 0.0059 & -0.1741 & 0.0209 & -0.0001 & 0.0000 & 0.0001 & \\
\hline MV3 & & 0.0001 & 0.0133 & -0.0152 & 0.0009 & 1.7221 & 0.0000 & 0.0001 & \\
\hline
\end{tabular}

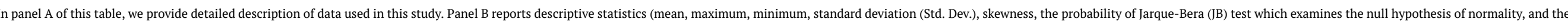
$\operatorname{ADF}(1981)$ unit root test results (the probability of the null hypothesis that there is a unit root). The last column notes the sample period for each country. 
To test the efficiency of volatility measures in our data and also the robustness of our results, we use three very common volatility measures which have been used in many insightful papers (see, for example, Sharma et al., 2014). Volatility measures at the country level and for the five aggregate Asian economies are defined in Panel A of Table 1.

\section{B. Methodology}

According to Sharma et al. (2014), the main focus of previous studies has been on measuring individual volatility regarding the firm or the market and the literature has established an analytical framework which links the volatility of the market as the collective volatility of firms that make up the market. Using their analytical framework, we propose that the country-level market volatility in the Asian region is essentially the collective volatility of markets that make up the region. The following time-series regression model is, therefore, employed:

$$
\begin{array}{r}
V_{c, t}=\alpha+\beta_{1} V_{r, t}+e_{t} \\
h_{t}^{2}=\gamma+\delta_{1} e_{t-1}^{2}+\delta_{2} h_{t-1}^{2} \\
e_{t}=h_{t} \vartheta_{t} \$ ; \$ \vartheta_{t} \sim N(0,1)
\end{array}
$$

In these equations, $V_{c}$ represents volatility at the country level and $V_{r}$ represents volatility at the region level, which is simply the sum of volatilities of the five Asian economies. We estimate Equation (1) using a standard GARCH $(1,1)$ model by considering four sample periods to draw conclusions of the effects of the COVID-19 pandemic on Asian economies. Our first sample covers the full sample period (each country has a different start date, but the end date is the same, which is $09 / 25 / 2020$ ). The second sample covers the period till $12 / 30 / 2019$ and we refer to this as the preCOVID-19 sample. The third sample contains data for the COVID-19 period (12/31/2019 - 09/25/2020) and for the final sample, we match the COVID-19 sample with a preCOVID-19 sample in order to maintain the same number of observations (01/01/2019 - 12/30/2019). It is also important to note that given we use three different measures of volatility, we estimate Equation (1) three times for each country using different sample periods. A log likelihood function is maximised on the assumption of conditional normality of the country level volatility shock, $e_{t}$, and we derive the statistical significance based on the procedure recommended by Bollerslev \& Wooldridge (1992). Equation (2) represents the variance equation of the GARCH estimation approach.

\section{Results}

A preliminary analysis of the data is presented in Panel $B$ of Table 1. First, we note that regardless of the volatility measure, the null hypothesis of a unit root based on the ADF (1981) test is rejected at the $1 \%$ statistical significance level for all five Asian economies. This implies that all variables follow a stationary process. Second, we note that the mean value of all three volatility measures for all Asian economies is in the range $0.0001-0.0003$; however, the skewness statistics are different for different measures of volatility. This implies that the Asian markets are different and aggregate volatility maybe connected to the country level volatility differently.

Next, we move to our main findings. The results pertaining to the commonality in volatility for each of the five Asian economies are reported in Table 2. Three sets of results are reported which are simply based on the use of three different measures of volatility. First, in Panel A re- sults are based on the first measure of volatility, $V_{1}$. We note that in the case of Japan, Singapore, and S. Korea the impact of aggregate Asian regional market volatility on country-level volatility is greater during the COVID-19 period compared to the two pre-COVID-19 periods. However, the impact of Asian regional market volatility on country level volatility of HK and Russia is found to be more prominent when the COVID-19 period is excluded. In other words, our findings suggest that during the COVID-19 pandemic, there are potentially other factors which can better explain the country-level volatility of HK and Russia, while for Japan, Singapore and S. Korea, the commonality in volatility is much stronger during the COVID-19 period.

Next, when we consider the other two measures of volatility, we find that only in the case of Singapore, the estimated coefficient of regional market volatility is greater during the COVID-19 period. For the remaining four Asian economies, we find that the regional market volatility explains country-level volatility much better during preCOVID-19 periods.

Overall, we note that regardless of the use of different measures of volatility, the aggregate Asian regional market volatility has a statistically significant effect on countrylevel market volatility for all five developed Asian economies. However, the strength of commonality in volatility is not only country-dependent but sensitive to different measures of volatility.

\section{Concluding remarks}

There is limited work done with respect to "spillover" and/or "contagion effect" between market volatilities at aggregate and disaggregate levels. The shock to the global economy from COVID-19 has been faster and more severe. Markets have become volatile as a result of the pandemic. We, therefore, examine whether aggregate regional level market volatility has a significant effect on country-level market volatility in the case of five developed Asian economies. Using daily data, we show that there exists a significant relationship between Asian regional level stock market volatility and country-level stock market volatility. Additionally, we also report that in the case of Singapore, the regional level market volatility is more stronger during the COVID-19 period compared to pre-COVID-19 periods.

We would like to acknowledge that one limitation of our work is that we do not explain why the commonality in volatility increased only in the case of Singapore during the COVID-19 period compared to the other four Asian economies. Future studies can include other factors in the model and examine the robustness of our findings and may provide some insights on why the case of Singapore is different from the other Asian economies.

Submitted: October 12, 2020 AEDT, Accepted: October 21, 2020 AEDT 
Table 2: Results on commonality in volatility

\begin{tabular}{|c|c|c|c|c|c|c|}
\hline & & Hong Kong & Japan & Russia & Singapore & South Korea \\
\hline \multirow{4}{*}{ Panel A: $V_{1}$} & Full Sample & $\begin{array}{l}0.1086^{* * *} \\
(0.0000)\end{array}$ & $\begin{array}{l}0.1692^{* * *} \\
(0.0000)\end{array}$ & $\begin{array}{l}0.3483^{* * *} \\
(0.0000)\end{array}$ & $\begin{array}{l}0.0539^{* * *} \\
(0.0000)\end{array}$ & $\begin{array}{l}0.1094^{* * *} \\
(0.0000)\end{array}$ \\
\hline & $\begin{array}{l}\text { Pre-COVID19 } \\
\text { Sample } 1\end{array}$ & $\begin{array}{l}0.1051^{* * *} \\
(0.0000)\end{array}$ & $\begin{array}{l}0.1687^{* * *} \\
(0.0000)\end{array}$ & $\begin{array}{l}0.3593^{* * *} \\
(0.0000)\end{array}$ & $\begin{array}{l}0.0414^{* * *} \\
(0.0000)\end{array}$ & $\begin{array}{l}0.1082^{* * *} \\
(0.0000)\end{array}$ \\
\hline & $\begin{array}{l}\text { Pre-COVID19 } \\
\text { Sample } 2\end{array}$ & $\begin{array}{l}0.3478^{* * *} \\
(0.0000)\end{array}$ & $\begin{array}{l}0.1139^{* * *} \\
(0.0000)\end{array}$ & $\begin{array}{l}0.1355^{* * *} \\
(0.0000)\end{array}$ & $\begin{array}{l}0.1071^{* * *} \\
(0.0000)\end{array}$ & $\begin{array}{l}0.2432^{* * *} \\
(0.0000)\end{array}$ \\
\hline & $\begin{array}{l}\text { COVID19 } \\
\text { sample }\end{array}$ & $\begin{array}{l}0.1256^{* * *} \\
(0.0000)\end{array}$ & $\begin{array}{l}0.2516^{* * *} \\
(0.0000)\end{array}$ & $\begin{array}{l}0.1639^{* * *} \\
(0.0000)\end{array}$ & $\begin{array}{l}0.1327^{* * *} \\
(0.0000)\end{array}$ & $\begin{array}{l}0.3084^{* * *} \\
(0.0000)\end{array}$ \\
\hline \multirow{4}{*}{ Panel B: $V_{2}$} & Full Sample & $\begin{array}{l}0.1209^{* * *} \\
(0.0000)\end{array}$ & $\begin{array}{l}0.1001^{* * *} \\
(0.0000)\end{array}$ & $\begin{array}{c}0.4384 \\
(0.0000)\end{array}$ & $\begin{array}{l}0.0626^{* * *} \\
(0.0000)\end{array}$ & $\begin{array}{l}0.0853^{* * *} \\
(0.0000)\end{array}$ \\
\hline & $\begin{array}{l}\text { Pre-COVID19 } \\
\text { Sample } 1\end{array}$ & $\begin{array}{l}0.1204^{* * *} \\
(0.0000)\end{array}$ & $\begin{array}{l}0.0983^{* * *} \\
(0.0000)\end{array}$ & $\begin{array}{l}0.5883^{* * *} \\
(0.0000)\end{array}$ & $\begin{array}{l}0.0598^{* * *} \\
(0.0000)\end{array}$ & $\begin{array}{l}0.1052^{* * *} \\
(0.0000)\end{array}$ \\
\hline & $\begin{array}{l}\text { Pre-COVID19 } \\
\text { Sample } 2\end{array}$ & $\begin{array}{l}0.2616^{* * *} \\
(0.0000)\end{array}$ & $\begin{array}{l}0.2650^{* * *} \\
(0.0000)\end{array}$ & $\begin{array}{l}0.1340^{* * *} \\
(0.0000)\end{array}$ & $\begin{array}{l}0.0733^{* * *} \\
(0.0000)\end{array}$ & $\begin{array}{l}0.2636^{* * *} \\
(0.0000)\end{array}$ \\
\hline & $\begin{array}{l}\text { COVID19 } \\
\text { sample }\end{array}$ & $\begin{array}{l}0.1067^{* * *} \\
(0.0000)\end{array}$ & $\begin{array}{l}0.2523^{* * *} \\
(0.0000)\end{array}$ & $\begin{array}{l}0.1481^{* * *} \\
(0.0000)\end{array}$ & $\begin{array}{l}0.1328^{* * *} \\
(0.0000)\end{array}$ & $\begin{array}{l}0.0764^{* * *} \\
(0.0000)\end{array}$ \\
\hline \multirow{4}{*}{ Panel C: $V_{3}$} & Full Sample & $\begin{array}{l}0.1186^{* * *} \\
(0.0000)\end{array}$ & $\begin{array}{l}0.0551^{* * *} \\
(0.0000)\end{array}$ & $\begin{array}{l}0.6779^{* * *} \\
(0.0000)\end{array}$ & $\begin{array}{l}0.0369^{* * *} \\
(0.0000)\end{array}$ & $\begin{array}{l}0.0845^{* * *} \\
(0.0000)\end{array}$ \\
\hline & $\begin{array}{l}\text { Pre-COVID19 } \\
\text { Sample } 1\end{array}$ & $\begin{array}{l}0.1189^{* * *} \\
(0.0000)\end{array}$ & $\begin{array}{l}0.0867^{* * *} \\
(0.0000)\end{array}$ & $\begin{array}{l}0.6844^{* * *} \\
(0.0000)\end{array}$ & $\begin{array}{l}0.0384^{* * *} \\
(0.0000)\end{array}$ & $\begin{array}{l}0.0831^{* * *} \\
(0.0000)\end{array}$ \\
\hline & $\begin{array}{l}\text { Pre-COVID19 } \\
\text { Sample } 2\end{array}$ & $\begin{array}{l}0.2137^{* * *} \\
(0.0000)\end{array}$ & $\begin{array}{l}0.4325^{* * *} \\
(0.0000)\end{array}$ & $\begin{array}{l}0.1047^{* * *} \\
(0.0000)\end{array}$ & $\begin{array}{l}0.0643^{* * *} \\
(0.0000)\end{array}$ & $\begin{array}{l}0.2147^{* * *} \\
(0.0000)\end{array}$ \\
\hline & $\begin{array}{l}\text { COVID19 } \\
\text { sample }\end{array}$ & $\begin{array}{l}0.0843^{* * *} \\
(0.0000)\end{array}$ & $\begin{array}{l}0.2977^{* * *} \\
(0.0000)\end{array}$ & $\begin{array}{l}0.2367^{* * *} \\
(0.0000)\end{array}$ & $\begin{array}{l}0.1124^{* * *} \\
(0.0000)\end{array}$ & $\begin{array}{l}0.1507^{* * *} \\
(0.0000)\end{array}$ \\
\hline
\end{tabular}

This table reports result based on the following regression model: $V_{c, t}=\alpha+\beta_{1} V_{r, t}+e_{t}$. Here $V_{c, t}$ is country-level market volaility and $V_{r, t}$ represents market volatility at the regional level. We use three measures of volatility, which are defined in Table 1 . We estimate the regression model using data for the full sample period, 2 pre-COVID-19 samples and a sample covering the COVID-19 period (12/31/2019 - 09/25/2020). The pre-COVID-19 sample 1 represents data prior to 12/31/2019 (each country has different start dates), whereas the preCOVID-19 sample 2 contains data from 01/01/2019 - 12/30/2019. Finally, ${ }^{* * * *}$ represents statistical significance at $1 \%$ level. 


\section{REFERENCES}

Bollerslev, T., \& Wooldridge, J. M. (1992). Quasimaximum likelihood estimation and inference in dynamic models with time-varying covariances. Econometric Reviews, 11(2), 143-172. https://doi.org/ $\underline{10.1080 / 07474939208800229}$

Chen, C., Liu, L., \& Zhao, N. (2020). Fear sentiment, uncertainty, and bitcoin price dynamics: The case of COVID-19. Emerging Markets Finance and Trade, 56(10), 2298-2309. https://doi.org/10.1080/1540496 $\underline{\mathrm{x} .2020 .1787150}$

Devpura, N., Narayan, P. K., \& Sharma, S. S. (2019). Structural instability and predictability. Journal of International Financial Markets, Institutions and Money, 63, 101145. https://doi.org/10.1016/j.intfin.20 $\underline{19.101145}$

Dickey, D. A., \& Fuller, W. A. (1981). Likelihood ratio statistics for autoregressive time series with a unit root. Econometrica, 49(4), 1057-1072. https://doi.or $\mathrm{g} / 10.2307 / 1912517$

Forbes, K. J., \& Rigobon, R. (2002). No contagion, only interdependence: measuring stock market comovements. Journal of Finance, 57(5), 2223-2261. htt ps://doi.org/10.1111/0022-1082.00494

German, M. B., \& Klass, M. J. (1980). On the estimation of security price volatilities from historical data. Journal of Business, 53, 67-78. https://www.jsto r.org/stable/2352358

Gu, X., Ying, S., Zhang, W., \& Tao, Y. (2020). How do firms respond to COVID-19? First evidence from Suzhou, China. Emerging Markets Finance and Trade, 56(10), 2181-2197. https://doi.org/10.1080/1540496 X.2020.1789455

Haroon, O., \& Rizvi, S. A. R. (2020). Flatten the curve and stock market liquidity-An Inquiry into emerging economies. Emerging Markets Finance and Trade, 56(10), 2151-2161. https://doi.org/10.1080/1540496 $\underline{\mathrm{X} .2020 .1784716}$

He, P., Niu, H., Sun, Z., \& Li, T. (2020). Accounting index of COVID-19 impact on Chinese industries: A case study using big data portrait analysis. Emerging Markets Finance and Trade, 56(10), 2332-2349. http s://doi.org/10.1080/1540496x.2020.1785866

Iyke, B. N. (2020). COVID-19: The reaction of US oil and gas producers to the pandemic. Energy Research Letters, 1(2), 13912. https://doi.org/10.46557/001c.13 $\underline{912}$
Liu, L., Wang, E.-Z., \& Lee, C.-C. (2020). Impact of the COVID-19 pandemic on the crude oil and stock markets in the US: A time-varying analysis. Energy Research Letters, 1(1), 13154. https://doi.org/10.4655 $\underline{7 / 001 \mathrm{c} .13154}$

Mishra, A. K., Rath, B. N., \& Dash, A. K. (2020). Does the Indian financial market nosedive because of the COVID-19 outbreak, in comparison to after demonetisation and the GST? Emerging Markets Finance and Trade, 56(10), 2162-2180. https://doi.or $\mathrm{g} / 10 / 1080 / 1540496 X .2020 .1785425$

Parkinson, M. (1980). The extreme value method for estimating the variance of the rate of return. Journal of Business, 53, 61-65. https://www.jstor.org/stable/2 $\underline{352357}$

Phan, D. H. B., \& Narayan, P. K. (2020). Country responses and the reaction of the stock market to COVID-19-a Preliminary Exposition. Emerging Markets Finance and Trade, 56(10), 2138-2150. http s://doi.org/10.1080/1540496x.2020.1784719

Rigobon, R. (2003). On the measurement of the international propagation of shocks: Is the transmission stable? Journal of International Economics, 61(2), 261-283. https://doi.org/10.1016/s 0022-1996(03)00007-2

Rodriguez, J. C. (2007). Measuring financial contagion: A copula approach. Journal of Empirical Finance, 14(3), 401-423. https://doi.org/10.1016/i.je mpfin.2006.07.002

Rogers, L. C. G., \& Satchell, S. E. (1991). Estimating variance from high, low, and closing prices. Annals of Applied Probability, 1, 500-512. https://www.jstor.or $\mathrm{g} / \mathrm{stable} / 2959703$

Rogers, L. C. G., Satchell, S. E., \& Yoon, Y. (1994). Estimating the volatility of stock prices: A comparison of methods that use high and low prices. Applied Financial Economics, 4(3), 241-247. https://d oi.org/10.1080/758526905

Sha, Y., \& Sharma, S. S. (2020). Research on Pandemics Special Issue of the Journal Emerging Markets Finance and Trade. Emerging Markets Finance and Trade, 56(10), 2133-2137. https://doi.or $\mathrm{g} / 10.1080 / 1540496 x .2020 .1795467$

Sharma, S. S., Narayan, P. K., \& Zheng, X. (2014). An analysis of firm and market volatility. Economic Systems, 38(2), 205-220. https://doi.org/10.1016/j.ec osys.2013.12.003 
Shen, H., Fu, M., Pan, H., Yu, Z., \& Chen, Y. (2020). The impact of the COVID-19 pandemic on firm performance. Emerging Markets Finance and Trade, 56(10), 2213-2230. https://doi.org/10.1080/1540496 х.2020.1785863

Wang, Y., Zhang, D., Wang, X., \& Fu, Q. (2020). How does COVID-19 affect China's insurance market? Emerging Markets Finance and Trade, 56(10), 2350-2362. https://doi.org/10.1080/1540496x.2020.1 $\underline{791074}$

Xiong, H., Wu, Z., Hou, F., \& Zhang, J. (2020). Which firm-specific characteristics affect the market reaction of Chinese listed companies to the COVID-19 pandemic? Emerging Markets Finance and Trade, 56(10), 2231-2242. https://doi.org/10.1080/15 40496x.2020.1787151
Yu, Z., Xiao, Y., \& Li, Y. (2020). The response of the labor force participation rate to an epidemic: Evidence from a cross-country analysis. Emerging Markets Finance and Trade, 56(10), 2390-2407. http s://doi.org/10.1080/1540496X.2020.1784717

Yue, P., Korkmaz, A. G., \& Zhou, H. (2020). Household financial decision making amidst the COVID-19 pandemic. Emerging Markets Finance and Trade, 56(10), 2363-2377. https://doi.org/10.1080/1540496 $\underline{\mathrm{X} .2020 .1787149}$

Zhang, F., Narayan, P. K., \& Devpura, N. (2020). Has COVID-19 changed the stock return oil price predictability pattern (working paper). 